\title{
Population dynamics and feeding ecology of the invasive Caucasian dwarf goby, Knipowitschia caucasica, in a freshwater habitat in Ukraine
}

\author{
Alexander Didenko ${ }^{1, *}$, Igor Buzevych ${ }^{1}$, Yuriy Volikov ${ }^{2}$, Svitlana Kruzhylina ${ }^{1}$ and Alexander Gurbyk ${ }^{1}$ \\ ${ }^{1}$ Institute of Fisheries of the National Academy of Agrarian Sciences of Ukraine, Obukhivska St. 135, 03164 Kyiv, Ukraine \\ ${ }^{2}$ Institute of Hydrobiology of the National Academy of Sciences of Ukraine, Prospekt Geroiv Stalingradu, 12, 04210 Kyiv, Ukraine
}

Received: 25 March 2020 / Accepted: 9 May 2020

\begin{abstract}
Population dynamics and feeding patterns of invasive Knipowitschia caucasica were studied in the littoral zone of the lower Stugna River. The abundances of this goby showed significant inter-annual and seasonal fluctuations. The studied population of $K$. caucasica was represented by two age groups ( 0 and I). Fish die after their first breeding season. In total, 58 prey items were identified in the diet of $K$. caucasica at the sampling site. The most abundant prey were copepods and cladocerans, while the most frequently encountered prey were copepods and chironomid larvae. Copepods were represented mainly by Cyclopoidae. Cladocerans included 21 taxa, among which the most abundant were Diaphanosoma sp., Acroperus harpae, and Disparalona rostrata; chironomids included 22 taxa, among which the most abundant was Cricotopus sylvestris. The diet composition showed seasonal dynamics, where copepods predominated in January to April and in August-September, chironomid larvae were especially important in May to July, while cladocerans were most important in November-December. The relatively high diversity of both phytophilous and open-bottom-dwelling prey organisms in the stomach contents of K. caucasica indicates that this species fed on a large variety of benthic habitats including among macrophytes and open areas.
\end{abstract}

Keywords: Gobiidae / invasive species / fish diet / fish growth / population dynamics

Résumé - Dynamique des populations et écologie de l'alimentation du gobie nain du Caucase, Knipowitschia caucasica, dans un habitat d'eau douce en Ukraine. La dynamique des populations et les modes d'alimentation de Knipowitschia caucasica, espèce envahissante, ont été étudiés dans la zone littorale du cours inférieur de la Stugna. Les abondances de ce gobie ont montré d'importantes fluctuations interannuelles et saisonnières. La population étudiée de $K$. caucasica était représentée par deux groupes d'âge $(0$ et $\mathrm{I})$. Les poissons meurent après leur première saison de reproduction. Au total, 58 proies ont été identifiées dans le régime alimentaire de $K$. caucasica sur le site d'échantillonnage. Les proies les plus abondantes étaient les copépodes et les cladocères, tandis que les proies les plus fréquemment rencontrées étaient les copépodes et les larves de chironomes. Les copépodes étaient principalement représentés par des Cyclopoïdes. Les cladocères comptaient 21 taxons, parmi lesquels les plus abondants étaient Diaphanosoma sp., Acroperus harpae et Disparalona rostrata; les chironomes comptaient 22 taxons, parmi lesquels le plus abondant était Cricotopus sylvestris. La composition du régime alimentaire a montré une dynamique saisonnière, où les copépodes prédominaient de janvier à avril et en août-septembre, les larves de chironomes étaient particulièrement importantes de mai à juillet, tandis que les cladocères étaient les plus importants en novembre-décembre. La diversité relativement élevée, dans l'estomac de $K$. caucasica, des organismes proies phytophiles et des organismes proies vivant dans le sédiment indique que cette espèce se nourrissait d'une grande variété d'habitats benthiques, y compris parmi les macrophytes et les zones ouvertes.

Mots clés : Gobiidae / espèces envahissantes / régime alimentaire des poissons / croissance des poissons / dynamique des populations

\footnotetext{
*Corresponding author: al_didenko@yahoo.com
} 


\section{Introduction}

The Caucasian dwarf goby, Knipowitschia caucasica (Berg, 1916), is a small Ponto-Caspian gobiid, the maximum length (SL) of which rarely exceeds $4.0 \mathrm{~cm}$ (Smirnov, 1986). This is a euryhaline species, which inhabits saline, fresh and estuarine waters along coasts of the Black, Azov, Caspian and Aegean Seas (Kottelat and Freyhof, 2007). It can live in a wide range of salinities from freshwater to $54.9 \%$ (Koblitskaya, 1961). This goby is most abundant in shallow waters near the border of macrophyte beds and on open areas of muddy bottoms (Smirnov, 1986).

The Caucasian dwarf goby has successfully established in freshwater bodies around the Black Sea and Mediterranean region. These include the Metsamor River and Ararat Valley reservoirs of Armenia (Gabrielyan, 2001); Lake Trichonis, Aliakmon and Itamos Rivers in Greece (Daoulas et al., 1993, Economidis et al., 1981, Economidis and Miller, 1990); some water bodies of the Tisza River basin in Hungary and Serbia (Harka et al., 2015a, 2015b; Antal et al., 2015); a number of water bodies in Turkey including Eğirdir, Eber, Sapanca, Beysehir and Büyükçekmece lakes and the Evros river basin (Neer et al., 1999; Balık et al., 2005; Özuluğ et al., 2007; Güçlü and Erdoğan, 2017). The first record of the Caucasian dwarf goby in Ukrainian freshwaters is dated to 2006, when one specimen of this species was caught in the Dnieper Reservoir in Zaporizhia region (Pan'kov, 2007). This goby also occurs in the Siverskyi Donets River in the Kharkiv region about $1000 \mathrm{~km}$ from the Sea of Azov, where it was first recorded in 2009 (Shandikov et al., 2009; Goncharov, 2014).

Information on the diet of the Caucasian dwarf goby in invaded freshwaters is very scant (e.g., Güçlü and Erdoğan, 2017). However, the knowledge of the feeding habits of this gobiid in freshwater may be important for assessing its effect on native species and more generally on the invaded ecosystems.

The aim of the study was to investigate the seasonal population dynamics and feeding patterns of the Caucasian dwarf goby in a freshwater habitat in the lower Stugna River, where this goby has successfully established and became quite abundant. This river flows into the Kaniv reservoir, which is one of six reservoirs built on the Dnieper River. There is no precise information when the Caucasian dwarf goby penetrated into the Kaniv reservoir and the Stugna River as small fish were probably initially identified as juveniles of other gobiids (Pan'kov, 2007).

\section{Materials and methods}

\subsection{Fish sampling}

Fish were caught in the littoral zone of the lower Stugna River in Ukrainka city, Kyiv region, Ukraine, along a length of approximately $70 \mathrm{~m}$ of the right river bank and approximately $1100 \mathrm{~m}$ from the inflow to the Kaniv reservoir (N 50 $08^{\circ}$, 57.16", E $\left.30^{\circ} 43^{\prime} 55.05^{\prime \prime}\right)$. The substrate at the sampling station was primarily sand and muddy sand with patches of dense macrophyte beds consisting mainly of Myriophyllum sp., Ceratophyllum sp., Potamogeton spp., which covered approximately $40 \%$ of the site area. River width at the sampling site was $85 \mathrm{~m}$; current velocity was usually less than $0.05 \mathrm{~m} / \mathrm{sec}$.
Sampling was performed monthly from March 2015 to February 2016 and from March 2018 to November 2018, usually between the 15th and 20th days of the month and between $9 \mathrm{~h} 00$ and $12 \mathrm{~h} 00$.

Fish were caught using a beach seine made of mill sieve gauze $(10 \mathrm{~m}$ long $\times 1 \mathrm{~m}$ high with $1.0 \mathrm{~mm}$ bar mesh size). Three hauls were made during each sampling day covering approximately $30 \mathrm{~m}^{2}$ each. The total hauled area was approximately $90-100 \mathrm{~m}^{2}$ and included both vegetated and non-vegetated substrates. The maximum depths within the hauled area were $1.2 \mathrm{~m}$. Fish from all hauls within one sampling event were pooled, identified and counted. If enough fish were caught, up to 30 specimens of the Caucasian dwarf goby were randomly selected and preserved in a $4 \%$ formaldehyde solution and processed later in the laboratory. The remaining fish were counted and released. Fish caught in 2018 were only counted and up to 40 individuals, if available, from each sampling event were measured. In total, 1183 Caucasian dwarf goby specimens were caught during the study period and 315 of them were collected for gut content analysis.

Zooplankton samples were collected in 2015-2016 approximately $30 \mathrm{~min}$ after fish sampling using a conical plankton net (opening diameter $25 \mathrm{~cm}$, mesh size $125 \mu \mathrm{m}$ ). The net was hauled vertically from the bottom to the water surface over a depth of $1.2 \mathrm{~m}$. Five zooplankton samples were taken randomly at five different locations within the hauling area, pooled, filtered through a $125 \mu \mathrm{m}$ plankton net and preserved in a $4 \%$ formaldehyde solution for laboratory processing. Water temperature in the hauled area was measured using an electronic thermometer with a probe at a depth of $0.5 \mathrm{~m}$ below the water surface.

The samples of benthic macroinvertebrates were collected in 2015-2016 using an Ekman grab with a sampling area of $208 \mathrm{~cm}^{2}$ from a depth of 1.0-1.2 m. All samples were sieved through a $0.5 \mathrm{~mm}$ mesh, individual macroinvertebrates were sorted and preserved in a $4 \%$ formaldehyde solution for laboratory processing.

In the laboratory, fish were measured to the nearest $1 \mathrm{~mm}$ (TL), weighed to the nearest $0.01 \mathrm{~g}$ using an electronic balanc and eviscerated. Only fish caught in 2015-2016 were used for the diet study. The gut contents of the entire digestive tract were removed and examined in a counting chamber under a binocular microscope. Prey items were identified to the lowest taxon wherever possible and counted. Benthic organisms were measured and their dry weights were calculated using published length-weight relationships (Benke et al., 1999). In addition, up to ten fish were randomly selected from each monthly sample and chironomid larvae from their stomachs were collected separately and preserved in Eppendorf tubes using a $4 \%$ formaldehyde solution. The chironomids collected from different fish stomachs were pooled by month and sent for identification by a specialist to the lowest taxonomic level possible. For zooplankton, the lengths of at least 20 individuals of each identified taxa were measured to the nearest $0.01 \mathrm{~mm}$ with an ocular micrometre. The dry weights of zooplankton and benthic organisms were estimated using published length-dry weight regression relationships (McCauley, 1984; Culver et al., 1985; Watkins et al., 2011). The obtained dry weight values of prey organisms were transformed into wet weight values assuming the water content 
of $85.0 \%$ for zooplankton and $76.0 \%$ for benthic organisms (USEPA, 2010).

Invertebrates from zooplankton and benthos samples were identified to the lowest possible level and counted under a binocular microscope in a counting chamber. Zooplankton abundance data were expressed as individuals $/ \mathrm{m}^{3}$, while the abundance of benthic macroinvertebrates was expressed as individuals $/ \mathrm{m}^{2}$. Chironomid larvae from benthos samples were arbitrarily divided into small ( $\leq 5 \mathrm{~mm}$ in length) and large $(>5 \mathrm{~mm}$ ) chironomids, which were used for comparing their abundances in the benthos (ind. $/ \mathrm{m}^{2}$ ) and fish stomach contents (ind. per fish).

\subsection{Data analysis}

Fish abundances on the sampling site at different months were calculated as the number of individuals collected per 100 $\mathrm{m}^{2}$ of a seine haul (CPUE).

The feeding activity was expressed as the index of stomach fullness (FI): FI $=$ (gut content weight $) /($ fish weight $) \times 100$, where gut content weight is the sum of the wet weights of prey items. Fish with empty stomachs were removed from the analysis.

Fish were arbitrarily divided into three length groups: $\leq 19 \mathrm{~mm}, 20-29 \mathrm{~mm}$, and $\geq 30 \mathrm{~mm}$. Diet compositions by month (all length groups combined) and by length group (all months combined) were described using following indices: frequency of occurrence $(\% \mathrm{~F})$, relative abundance $(\% \mathrm{~N})$, percentage of biomass $(\% \mathrm{~W})$, index of relative importance (IRI), and percent index of relative importance (\%IRI):

$$
\% F=f_{i} / \Sigma f \times 100
$$

where $f_{i}$ is the number of guts containing the prey item $i$ and $\Sigma f$ is the total number of non-empty guts;

$$
\% N=n_{i} / \Sigma n \times 100
$$

where $n_{i}$ is the total number of prey item $i$ and $\Sigma n$ is the total number of prey items consumed by fish;

$$
\% W=w_{i} / \Sigma w \times 100
$$

where $w_{i}$ is the total weight of prey item $i$ and $\Sigma w$ is the total weight of prey items consumed by fish; and

$$
\begin{gathered}
\text { IRI }=(\% N+\% W) \times F \% \\
\% I R I=I R I i / \Sigma I R I \times 100(\text { Liao et al., 2001). }
\end{gathered}
$$

As for the subsamples of chironomid taxa collected from fish stomachs, which were pooled by months and identified separately, it was not possible to calculate $\% F$ values. For them, only $\% N$ and $\% W$ values were calculated and then extrapolated to the total number of chironomids in fish gut contents.

One-way ANOVA with post-hoc Tukey-Kramer test was used to compare mean lengths of fish sampled in different months. Stomach fullness values as well as the numbers of the most abundant prey items in fish stomachs were logtransformed to meet the assumptions of normality. Prey items were grouped into larger categories (e.g., copepods, cladocerans, chironomids, etc.). Linear models (LM) were used to find the relationships between the stomach fullness index and water temperature, between the stomach fullness index and CPUEs, between CPUEs and water temperature, between the numbers of the most abundant prey items in fish stomachs and their abundances in zooplankton and benthos samples, between the numbers of taxonomic groups in fish diet and water temperature.

Statistical analyses were performed in JMP 10 (SAS Institute).

\section{Results}

\subsection{Water temperature and food abundance}

Water temperature at the sampling site rose gradually throughout a year from a minimum in January and reached a peak in August; then it started dropping gradually until December (Tab. 1). The abundances of copepods and cladocerans in zooplankton samples varied throughout a year with two peaks in May and August for copepods and a clear peak in May for cladocerans (Tab. 1). The abundance of benthic chironomid larvae at the sampling site also showed seasonal fluctuations, with the highest values observed in February-May and October-December and the lowest values during summer (Tab. 1). The highest abundances of smallsized chironomids in the benthos were observed in May and September-October.

\subsection{Population dynamics}

The abundances of the Caucasian dwarf goby in beach seine catches significantly varied both throughout a year and between studied years (Fig. 1). Mean CPUE values were significantly higher in $2018\left(130.3 \pm 52.7 \mathrm{SE} \mathrm{fish} / 100 \mathrm{~m}^{2}\right)$ compared to 2015-2016 (30.4 $\pm 8.3 \mathrm{SE}$ fish/100 $\left.\mathrm{m}^{2}\right)$. No significant relationship was found between the CPUEs of this species and water temperature (LM: $\left.F_{1,10}=0.0005, p>0.05\right)$.

The total lengths of the Caucasian dwarf goby in catches ranged from 13 to $37 \mathrm{~mm}$ with an average length of $28.4 \pm 0.26 \mathrm{~mm}$. Their mean total lengths significantly varied throughout a year (ANOVA: $F_{11,303}=37.2, p<0.001$ ), where the largest adult-sized specimens were usually caught during winter, spring, and fall, while juveniles dominated in the summer (Fig. 2). Juveniles and adults co-occurred in the littoral zone of the river only in June. Brood fish started disappearing from the sampling site in June and no adult-sized specimens were caught during July to September. Usually, no significant differences were observed between the average lengths of the Caucasian dwarf goby sampled in all months except the period from June to September (Tukey-Kramer test, $\alpha=0.05$ ). The length of adult fish was reached by the majority of YOYs in October.

\subsection{Feeding}

The feeding activity of the Caucasian dwarf goby showed clear seasonal dynamics, which depended on water temperature: $y=15.72( \pm 4.56 \mathrm{SE}) x+2.93( \pm 3.48 \mathrm{SE}) ; n=10 ; r^{2}=0.54$; $p=0.0063$. Juvenile fish usually had higher stomach fullness 
Table 1. Water temperature and abundances of major prey items of the Caucasian dwarf goby in the zooplankton and benthos samples at the sampling site in 2015-2016.

\begin{tabular}{llllll}
\hline Month & Water temperature, ${ }^{\circ} \mathrm{C}$ & \multicolumn{3}{c}{ Abundance } \\
\cline { 3 - 6 } & & $\begin{array}{l}\text { Copepods in } \\
\text { zooplankton, } \\
\text { ind. } \cdot 10^{3} \cdot \mathrm{m}^{-3}\end{array}$ & $\begin{array}{l}\text { Cladocerans } \\
\text { zooplankton, } \\
\text { ind. } \cdot 10^{3} \cdot \mathrm{m}^{-3}\end{array}$ & $\begin{array}{l}\text { All chironomids } \\
\text { in the benthos, } \\
\text { ind. } \cdot \mathrm{m}^{-2}\end{array}$ & $\begin{array}{l}\text { Small-sized chironomids } \\
\text { in the benthos, } \\
\text { ind. } \cdot \mathrm{m}^{-2}\end{array}$ \\
\hline Jan & 1.3 & 0.0 & 0.0 & $\mathrm{n} / \mathrm{a}$ & $\mathrm{n} / \mathrm{a}$ \\
Feb & 3.4 & 0.0 & 0.1 & 1296 & 64 \\
Mar & 3.8 & 1.5 & 4.3 & 528 & 48 \\
Apr & 11.8 & 0.2 & 0.8 & 1072 & 96 \\
May & 20.0 & 12.5 & 80.5 & 880 & 704 \\
Jun & 23.2 & 1.2 & 35.8 & 368 & 208 \\
Jul & 23.7 & 5.2 & 20.0 & 512 & 288 \\
Aug & 26.0 & 18.5 & 19.6 & 464 & 544 \\
Sep & 20.3 & 1.7 & 14.8 & 704 & 432 \\
Oct & 12.3 & 1.0 & 3.5 & 912 & 80 \\
Nov & 6.9 & 0.5 & 1.7 & 1088 & 288 \\
Dec & 4.1 & 0.3 & 0.9 & & \\
\hline
\end{tabular}

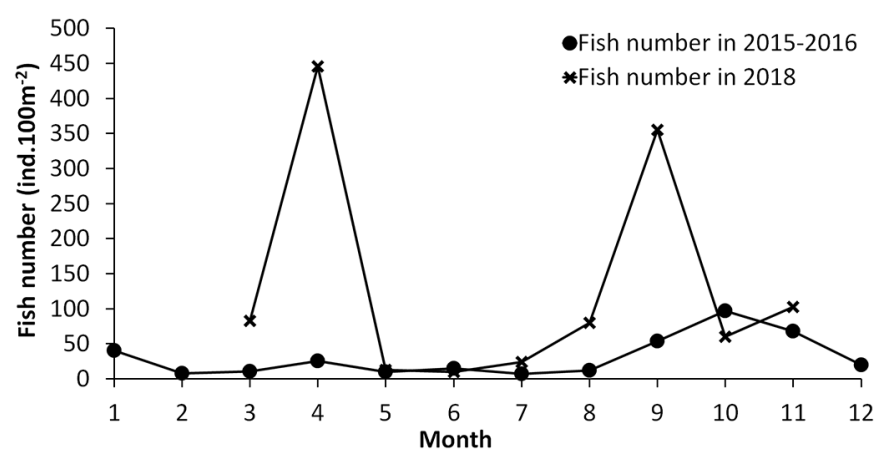

Fig. 1. Seasonal dynamics of the Caucasian dwarf goby abundance (CPUE) at the sampling site.

values than adult-sized fish (Fig. 3). The highest stomach fullness values of adult-sized fish were observed in April-May and October, while those of juveniles in June and September. The Caucasian dwarf goby fed very little during winter months. No significant relationship was found between the stomach fullness and CPUE values for both studied years (LM: $F_{1,11}=1.3019, p>0.05$, for $2015-2016 ; F_{1,8}=0.9876$, $p>0.05$, for 2018).

The numbers of individual prey items in the stomach contents ranged from 1 to $173($ mean $=15.1 \pm 1.2 \mathrm{SE})$ and $2.5 \%$ of fish had empty guts. The mean numbers of prey items varied among different size classes of the Caucasian dwarf goby and were $6.3 \pm 0.6 \mathrm{SE}, 16.5 \pm 2.0 \mathrm{SE}$, and $13.5 \pm 1.4 \mathrm{SE}$, respectively for small, medium, and large sized fish. No significant relationship between TL and the number of prey items in the stomach contents was found (LM: $F_{1,313}=0.2623, p>0.05$ ).

In total, 58 prey taxa were identified in the diet of the Caucasian dwarf goby in the Stugna River (Appendix Table AI). The most abundant prey were zooplanktonic organisms such as copepods and cladocerans accounting for $42.2 \%$ and $38.7 \%$ by number, respectively, while the most frequently encountered prey were copepods and chironomid larvae, which were observed in the gut contents of $77.1 \%$ and $67.0 \%$ of analysed fish, respectively. The latter ones dominated in the diet of the Caucasian dwarf goby by weight (43.0\%). Copepods were represented mainly by Cyclopoidae, cladocerans were represented by 21 taxa, while chironomids included 22 taxa. The Caucasian dwarf goby consumed mainly small-sized chironomid larvae with an average length of $3.7 \pm 0.8 \mathrm{SE} \mathrm{mm}$.

Among cladocerans, Bosmina longirostris and Chydorus sphaericus were more important in the diet of smallest specimens of the Caucasian dwarf goby (Appendix Table AII), while Acroperus harpae dominated in other size groups. Copepods were most important in the diet of the medium and somewhat less important in the diet of the largest size group, while chironomid larvae predominated in the diet of the smallest and largest size groups and were less important in the diet of the medium size group of this goby.

The diet composition of the Caucasian dwarf goby showed seasonal dynamics, where copepods significantly predominated in the stomach contents of adult-sized fish in January to April, while chironomid larvae were most important in MayJune and cladocerans were most important in NovemberDecember (Fig. 4). As for juvenile-sized fish, the most important preys in their diets were cladocerans in June, chironomid larvae in July and copepods in August-September.

Mean abundances of the most important groups of prey organisms in the stomach contents of the Caucasian dwarf goby at the sampling site showed seasonal dynamics, where the highest abundances of copepods in the stomach contents of adult-sized fish were observed in February to May, cladocerans in October to December, and chironomid larvae in May-June. The highest abundances of copepods in the stomach contents of juveniles were observed in July-September, cladocerans in June and in August, and chironomid larvae in July (Fig. 5).

No significant relationship was found between the abundances of copepods and cladocerans in zooplankton samples and their numbers in the gut contents of the Caucasian 
A. Didenko et al.: Knowl. Manag. Aquat. Ecosyst. 2020, 421, 26

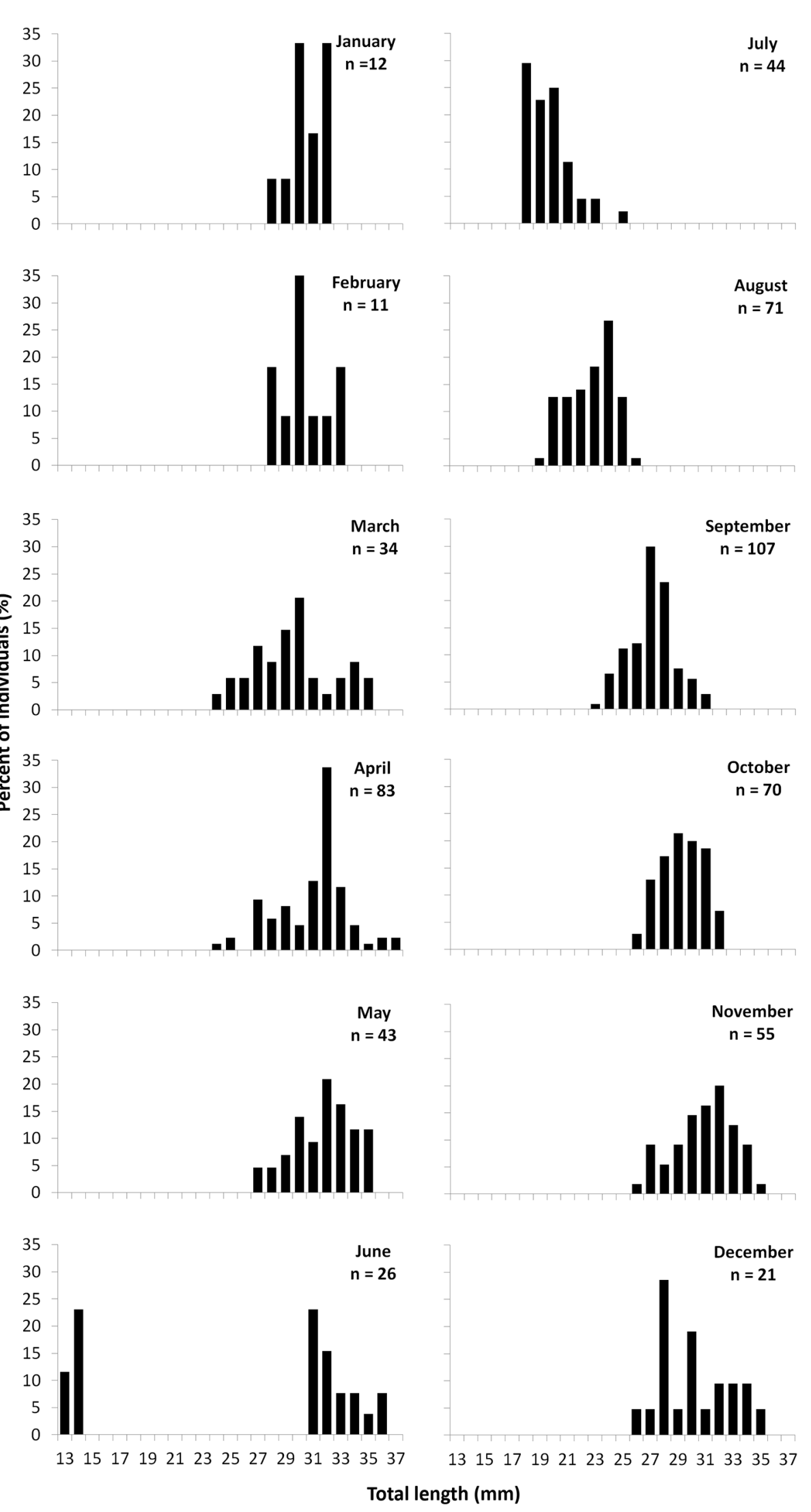

Fig. 2. Length-frequency histograms of the Caucasian dwarf goby caught at the sampling site in different months ( $\mathrm{n}=$ number of measured fish). 


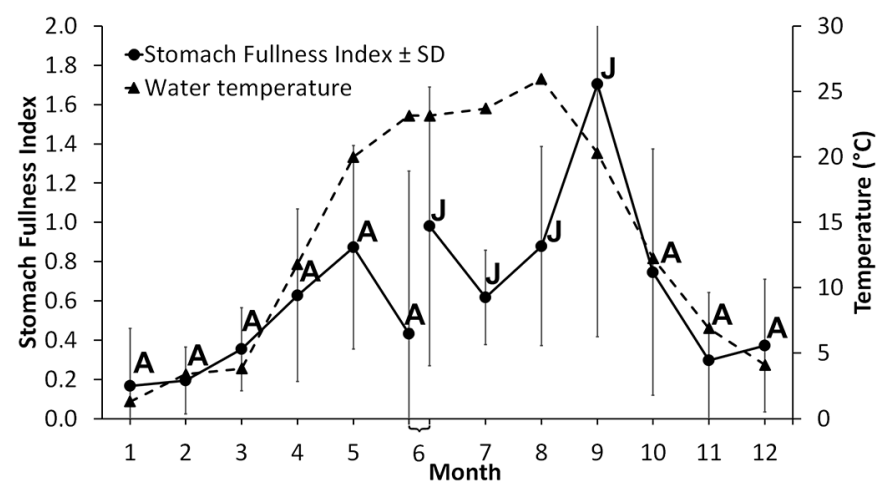

Fig. 3. Seasonal dynamics of of the stomach fullness index $( \pm \mathrm{SD})$ of the Caucasian dwarf goby and relationship with water temperature at the sampling site (A - adult-sized fish, $\mathrm{J}$ - juveniles).

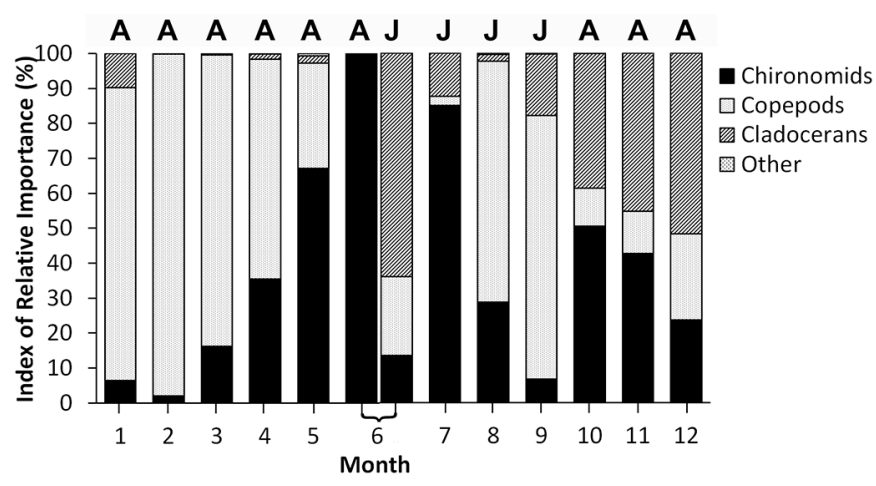

Fig. 4. Seasonal dynamics of the diet composition of the Caucasian dwarf goby at the sampling site based on the percent index of relative importance (\%IRI) (A - adult-sized fish, $\mathrm{J}$ - juveniles).

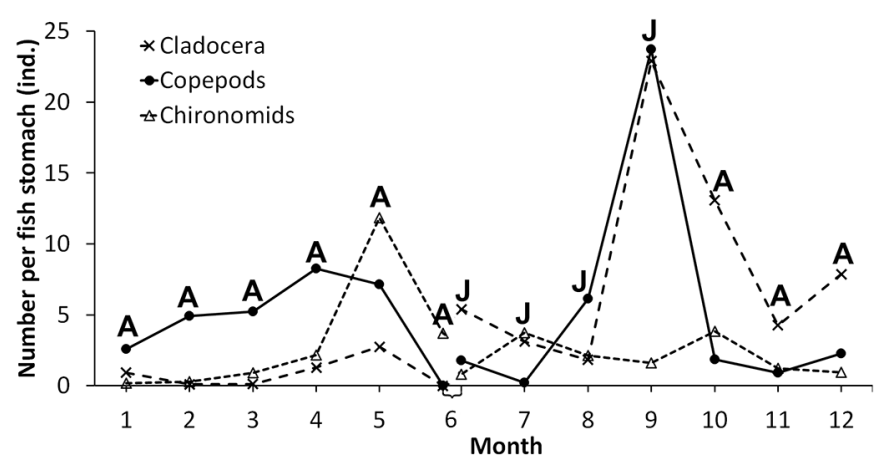

Fig. 5. Seasonal dynamics of mean abundances of most important groups of prey organisms in the stomach contents of the Caucasian dwarf goby at the sampling site $(\mathrm{N}$ per fish) (A - adult-sized fish, $\mathrm{J}$ - juveniles).

dwarf goby (LM: $F_{1,10}=0.0607, p>0.05$, for copepods; LM: $F_{1,10}=0.8355, p>0.05$, for cladocerans).

The chironomids consumed by the Caucasian dwarf goby were represented mainly by small-sized individuals and a significant relationship was observed between their abundances in fish stomachs and the abundances of smallsized chironomid larvae ( $\leq 5 \mathrm{~mm}$ in length) in the benthos: $y=0.7236( \pm 1.2705 \mathrm{SE}) x+0.0092( \pm 0.0038 \mathrm{SE}) ; \quad n=11 ; \quad r^{2}=$ $0.39 ; p=0.0390$ (Appendix Fig. A1). At the same time, no significant relationship was observed between the abundance of all benthic chironomids in the environment and their numbers in the gut content of the Caucasian dwarf goby (LM: $\left.F_{1,9}=0.0575, p>0.05\right)$.

\section{Discussion}

The Caucasian dwarf goby is a short-living species, the usual life span of which is often less than 2 years and which spawns after its first winter at 20-23 mm SL (Smirnov, 1986; Kevrekidis et al., 1990). Usually, such species display an $\mathrm{r}-$ strategy and form labile populations, which are characterized by significant inter-annual fluctuations in abundances responding to changes in environmental conditions. For example, the average annual CPUE of the Caucasian dwarf goby at the sampling site in 2018 exceeded that in 2015-2016 by 6.3 times and this exceedance was extremely high for some months (e.g., 22.3 times for April and 17.6 times for September). As the same fishing gear was used in both years and the sampling pattern was the same, these changes in abundances cannot be attributed to external factors affecting catchability. Such significant differences in inter-annual abundance are probably due to differences in environmental conditions before and during studied years, e.g., more favorable conditions during spawning or wintering compared to those of other years might result in rapid increases in the abundances of this goby.

Very high peaks of abundances of the Caucasian dwarf goby observed in April and September in 2018 can be caused by certain environmental factors, which stimulate fish to swarm in the littoral zone. For example, a peak in April could be due to the arrival and concentration of brood fish on their spawning ground. In the study of Baer et al. (2017), swarming events in the round goby, Neogobius melanostomus, correlated positively with water temperature. In our case, average water temperature at the sampling site in 2018 was somewhat higher than that in $2015\left(17.2 \pm 2.68^{\circ} \mathrm{C}\right.$ and $15.7 \pm 2.69^{\circ} \mathrm{C}$, respectively) and water temperatures in April and September were higher in 2018 compared to $2015\left(14.5^{\circ} \mathrm{C}\right.$ and $9.1^{\circ} \mathrm{C}$, respectively, for April and $21.5^{\circ} \mathrm{C}$ and $19.1^{\circ} \mathrm{C}$, respectively, for September). Moreover, some other gobiids have pulsed swarming events with still unknown triggers (Baer et al., 2017). Additional studies should be conducted to investigate these inter-annual and seasonal dynamics in the Caucasian dwarf goby abundances. However, such a pattern can also be due to the fact that the Caucasian dwarf goby probably penetrated into the Stugna River not long ago and is at the boom phase within boom-and-bust cycles of invasive species. These are typical for other gobiids (Adrian-Kalchhauser et al., 2016; Borcherding et al., 2016; Cerwenka et al., 2018).

Seasonal changes in the abundances and average sizes of the Caucasian dwarf goby within a year could be due to several casual mechanisms such as migrations to the littoral zone before spawning resulting in very high concentrations of this goby in April, then spawning in May and disappearance of adult fish in June, which probably die soon after spawning. A post-spawning die-off of brood Caucasian dwarf goby was also reported for Kuban estuaries in Russia (Troitskii and Tsunikova, 1978). Low numbers of sampled fish during 
summer months were probably due to the low accessibility of juveniles to the fishing gear used for sampling. An influx of small Caucasian dwarf goby with increases in their average sizes during summer months indicates recruitment of new young-of-the-years (YOYs) and their growth. Their abundances at the sampling site reached peaks in October in 2015 and in September in 2018. A decrease in the abundance of the Caucasian dwarf goby in the fall could be due to the migration of advanced YOYs from the littoral to deeper waters for wintering as well as their elimination by predators. A descend to deeper waters before winter is known for other populations of the Caucasian dwarf goby inhabiting brackish waters (Baimov, 1963; Kevrekidis et al., 1990).

Changes in the length distributions over time suggest that the population of the Caucasian dwarf goby at the sampling site was represented by two age groups ( 0 and I). YOYs of this species in the Stugna River showed a rapid growth during summer and reached the size of adult fish in October. Seasonal changes in fish length distributions suggest three periods. The first one (November to May) is a period of relatively stable average lengths with a slight increase in April-May, which was probably due to an increase in water temperature and beginning of active feeding of this species. The second one (June-July) is a period of a significant drop in the average length because of the appearance of YOYs in the samples. This period is characterized by the highest variability of fish lengths that is explained by the presence of at least two age groups at the sampling site: YOYs and age- 1 brood fish. The third is a period of stable growth (July-October). Increased variability in fish lengths after July indicates the possibility of intermittent spawning as observed in the native range of the Caucasian dwarf goby in Kuban estuaries (Troitskii and Tsunikova, 1978) and Evros Delta (Kevrekidis et al., 1990). The latter conclusion is also supported by the presence of some adultsized fish together with juveniles at the sampling site in June. These brood fish remain in the population and can participate in spawning in this month. For example, some egg-laden females of 31-36 mm TL were still observed in the samples in June and they completely disappeared from catches in July.

Average lengths of fish sampled in the Stugna River in the winter, spring, and fall months were significantly larger than those of fish caught in the corresponding months in the Evros Delta (Kevrekidis et al., 1990). This may indicate very favorable conditions for this species in this invaded freshwater. The life cycle of the Caucasian dwarf goby inhabiting the Stugna River is more similar to that of the foredelta of the Volga (Koblitskaya, 1961) and Kuban estuaries (Troitskii and Tsunikova, 1978), where age-1 brood fish also die after first spawning. In contrast, some individuals of the Caucasian dwarf goby inhabiting the Evros Delta survived after the first spawning and had a second breeding season (Kevrekidis et al., 1990), and in the Eğirdir Lake, where age- 3 fish reaching a length of $47 \mathrm{~mm}$ were observed (Güçlü and Erdoğan, 2017).

The Caucasian dwarf goby displayed distinct differences in diet compositions and food consumptions depending on fish size and season. The dependence of the feeding activity of the Caucasian dwarf goby on water temperature is typical for fish inhabiting temperate zone and was also observed in other gobiids (Borcherding et al., 2013; Všetičková et al., 2014). Juveniles usually had higher stomach fullness values than adult-sized fish. A similar pattern was also exhibited by Ponticola kessleri in the middle Danube, where the highest stomach fullness values were reported for the smallest individuals (Števove and Kováč, 2016). The stomach fullness values of the Caucasian dwarf goby started increasing from February to May with water temperature rise indicating a rise in active feeding during this period in order to increase energy reserves before spawning. A very high variability in the stomach fullness values in June was due to presence of both egg-laden and post spawning females. A drop in the stomach fullness of adult-sized fish observed in June may be due to a decrease in feeding activity of brood fish after spawning and before their die-off. A similar pattern of feeding activity with its significant decrease after May was also reported for other gobiids in invaded freshwaters such as Proterorhinus semilunaris and $N$. melanostomus, which can be connected with physical stress caused by reproductive activity (Adámek et al., 2010; Vašek et al., 2014).

Early juveniles of the Caucasian dwarf goby displayed active feeding in June and their feeding activity somewhat dropped in July and August. The maximum stomach fullness values were observed in advanced juveniles in September. The completely full stomachs of advanced YOYs of the Caucasian dwarf goby in September might be due to a decrease in their metabolism rates and high abundances of prey organisms in the environment. From September to winter months, a drop in food consumption occurred, which followed a decrease in water temperature and which might be attributable to a lack of available prey and reduced feeding activity. The feeding activity of the Caucasian dwarf goby did not show any dependence on their densities at the sampling site.

Besides seasonal differences in stomach fullness values, the Caucasian dwarf goby displayed seasonal differences in diet compositions that might be attributable to changes in prey availability as well as to differences in the sizes of sampled fish in different months. For example, the most important prey items in the diet of adult-sized goby in January to April were copepods, mainly cyclopoids, when other potential food was limited.

Chironomid larvae started dominating the diet of brood Caucasian dwarf goby in May and became the only food in June, probably due to a seasonal increase in their densities in the environment. The most important group of chironomids in the diet of the Caucasian dwarf goby at the sampling site was C. sylvestris gr., a common phytophilous chironomid living on aquatic plants, but which can also occur in sediments (Menzie, 1981). Other relatively abundant chironomids in the diet of the Caucasian dwarf goby at the sampling site were Parachironomus vitiosus, Paratanytarsus lauterborni, and Polypedilum convictum, which are sand- and mud-dwellers (Grzybkowska and Witczak, 1990; Özkan et al., 2010; Zinchenko, 2011).

Unfortunately, chironomid taxa in the environment at the sampling site were not identified and their abundances in the stomach contents of the Caucasian dwarf goby with those in sediments or on macrophytes could not be compared. However, a significant positive relationship between the numbers of small-sized chironomid larvae $(\leq 5 \mathrm{~mm}$ in length, all chironomid taxa pooled) in fish stomach contents and benthic samples suggests that the Caucasian dwarf goby selected mainly small-sized benthic chironomids including 
phytophilous species such as $C$. sylvestris gr., which probably lived in sediments near or under aquatic plants.

A significant part of the diet of early YOYs of the Caucasian dwarf goby sampled in June was composed of cladocerans (mainly chydorids and B. longirostris), when their abundances at the sampling site was the second highest after May. In addition, June as well as July were characterized by low abundances of copepods in the environment. This pattern is also typical for fry of other gobiids (e.g., N. melanostomus), a significant part of the diet of which also includes cladocerans and copepods (Hayden and Miner, 2009; Juza et al., 2015; Olson and Janssen, 2017). In July, the abundance of cladocerans in the environment at the sampling site dropped, while that of small-sized chironomid larvae significantly increased and one-month-old juvenile goby switched to the consumption of the latter. Copepods became the most important prey of two-month-old YOYs in August, when a second peak of their abundance in water at the sampling site occurred. A peak of both cyclopoid and cladoceran consumption by advanced juveniles of the Caucasian dwarf goby was observed in September; however, it did not correlate with their abundances in water at the sampling site in this month.

Cladocerans became more important in the diet of the Caucasian dwarf goby in October-December, when YOYs reached the sizes of adult fish. This could be due to a decline in the abundances of copepods during these months. Cladocerans seem to be less preferred prey for the adult-sized Caucasian dwarf goby as they were not abundant in fish stomach contents during their peaks in abundances in the environment observed in May-June. It is likely they were consumed when other preferred prey becomes not available. The most abundant cladocerans found in the stomach contents of the Caucasian dwarf goby in October-December were bottom-dwelling chydorids such as A. harpae, D. rostrata, and Alona spp., which accounted for $78.7 \%$ of all cladocerans by number during this period. Among them, A. harpae usually occurs among macrophytes (Duigan, 1992; Adamczuk, 2014), D. rostrata usually inhabits sites with little macrophyte growth (Duigan, 1992), while various Alona species occur on all substrate types (Duigan, 1992).

In sum, the diet of the Caucasian dwarf goby in the invaded Stugna Rivers was characterized by a higher variety of prey organisms compared to that from other available studies. There was little diversity in the diet of the Caucasian dwarf goby in the Egirdir Lake in Turkey, where it is also considered to be an invasive species. Fish here consumed mainly Ochrophyta, Gammarus pulex, and Ostracoda (Güçlü and Erdoğan, 2017). The diet of the Caucasian dwarf goby in its native range in the Evros Delta in Greece was also characterized by a relatively restricted diversity, including only six food categories of most abundant bottom-dwelling organisms inhabiting the sampling area, among which Gammarus aequicauda and two polychaetes such as Ficopomatus enigmaticus and Hediste diversicolor were the dominant preys, while the share of planktonic crustaceans was very low (Kevrekidis et al., 1990). In saline and brackish waters in Ukraine, this goby feeds mainly on Ostracoda and chironomid larvae (Smirnov, 1986). Advanced juveniles in the brackish Sasyk lagoon preyed mainly on amphipods (Burnahshev et al., 1958).
Zooplanktivorous habits of juvenile Caucasian dwarf goby observed in the Stugna River were also reported in its native range in the Kuban estuaries in Russia, where the dominant prey of 5-14 mm YOYs of this goby were copepods, while cladocerans became the dominant prey of 15-19 mm YOYs. Adult goby $(21-49 \mathrm{~mm})$ in the Kuban estuaries consumed mainly chironomid larvae and gammarids (Troitskii and Tsunikova, 1978). Thus, the feeding habits of the Caucasian dwarf goby inhabiting the Stugna River were more similar to those observed in the Kuban estuaries with the predominance of copepods, cladocerans, and chironomid larvae.

Based on the diet composition, which included a relatively high variety of both open-bottom-dwelling and phytophilous prey organisms, it can be concluded that the Caucasian dwarf goby in the Stugna River fed on a large variety of habitats including open non-vegetated areas and bottoms among macrophytes. This ability combined with other attributes (e.g., euryhalinity) can facilitate the successive establishment of this species in new areas and contribute to its wide distribution. Taking into account the diet composition of the Caucasian dwarf goby and its high abundances, it can indirectly affect cooccurring native fish species, especially those feeding on chironomid larvae, through competition. A short life span of this goby can result in significant fluctuations in its abundances, which depend on certain environmental factors; however, this question requires additional studies.

Acknowledgements. The authors would like to thank Nigel Adams, Environmental and Animal Sciences, Unitec, Auckland, New Zealand, for English-language suggestions and corrections.

\section{References}

Adamczuk M. 2014. Niche separation by littoral-benthic Chydoridae (Cladocera, Crustacea) in a deep lake - potential drivers of their distribution and role in littoral-pelagic coupling. J Limnol 73: 490-501.

Adámek Z, Jurajda P, Prášek V, Sukop I. 2010. Seasonal diet pattern of non-native tubenose goby (Proterorhinus semilunaris) in a lowland reservoir (Mušov, Czech Republic). Knowl Manag Aquat Ecol 397: 1-12.

Adrian-Kalchhauser I, Hirsch PE, Behrmann-Godel J, N'guyen A, Watzlawczyk S, Gertzen S, Borcherding J, Burkhardt-Holm P. 2016. The invasive bighead goby Ponticola kessleri displays largescale genetic similarities and small-scale genetic differentiation in relation to shipping patterns. Mol Ecol 25: 1925-1943.

Antal L, Székely C, Molnár K. 2015. Parasitic infections of two fish species, the Caucasian dwarf goby and the Amur sleeper, in Hungary. Acta Vet Hung 63: 472-484.

Baer J, Hartmann F, Brinker A. 2017. Invasion strategy and abiotic activity triggers for non-native gobiids of the River Rhine. PLoS ONE 12: e0183769.

Baimov U. 1963. Data on the biology of the bubyr goby Bubyr caucasicus (Berg) in the Aral Sea. Bulletin of the Karakalpak branch of AS of Uzbek SSR 3: 51-59 (in Russian).

Balık S, Ustaoğlu MR, Sarı HM, İlhan A, Topkara ET. 2005. The fish fauna of Yuvarlakçay (Köyceğiz, Muğla). Ege University Journal of Fisheries and Aquatic Sciences 22: 221-223 (in Turkish with English abstract) 
Benke AC, Huryn AD, Smock LA, Wallace JB. 1999. Length-mass relationships for freshwater macroinvertebrates in North America with particular reference to the southeastern United States. $J N \mathrm{Am}$ Benthol Soc 18: 308-343.

Borcherding J, Dolina M, Heermann L, Knutzen P, Krüger S, Matern S, van Treeck R, Gertzen S. 2013. Feeding and niche differentiation in three invasive gobies in the Lower Rhine, Germany. Limnologica 43: 49-58.

Borcherding J, Arndt H, Breiden S, Brenner K, Heermann L, Höfer S, Leistenschneider C, Lindner J, Staas S, Gertzen S. 2016. Drift of fish larvae and juveniles in the Lower Rhine before and after the goby invasion. Limnologica 59: 53-62.

Burnahshev MS, Chepurniv VS, Kubrak IF. 1958. Materials on ichthyofauna of the Sasyk lagoon. Trans Chisinau Univ 32: 63-72.

Cerwenka AF, Brandner J, Schliewen UK, Geist J. 2018. Population trends of invasive alien gobies in the upper Danube River: 10 years after first detection of the globally invasive round goby (Neogobius melanostomus). Aquat Invasions 13: 525-535.

Culver DA, Boucherle MM, Bean DJ, Fletcher JW. 1985. Biomass of freshwater crustacean zooplankton from length-weight regressions. Can J Fish Aquat Sci 42: 1380-1390.

Daoulas C, Economou AN, Psarras T, Barbieri-Tseliki R. 1993. Reproductive strategies and early development of three freshwater gobies. J Fish Biol 42: 749-776.

Duigan CA. 1992. The ecology and distribution of the litoral freshwater Chydoridae (Branchiopoda, Anomopoda) of Ireland, with taxonomic comments on some species. Hydrobiologia 241: $1-70$.

Economidis PS, Kattoulas ME, Stephanidis A. 1981. Fish fauna of the Aliakmon River and adjacent waters (Macedonia, Greece). Cybium 5: 89-95.

Economidis PS, Miller PJ. 1990. Systematics of freshwater gobies from Greece (Teleostei: Gobiidae). $J$ Zool 221: $125-170$

Gabrielyan BK. 2001. An annotated checklist of freshwater fishes of Armenia. Naga ICLARM Quarterly 24: 23-29.

Goncharov GL. 2014. Fish assemblage of river sandbanks near the Biological station of V.N. Karazin Kharkiv National University. The Journal of V.N. Karazin Kharkiv National University. Series: Biology 20: 122-128 (in Ukrainian).

Grzybkowska M, Witczak J. 1990. Distribution and production of Chironomidae (Diptera) in the lower course of the Grabia River (Central Poland). Freshw Biol 24: 519-531.

Güçlü SS, Erdoğan Ö. 2017. Age, growth, sex ratio and feeding of Knipowitschia caucasica (Berg, 1916) (Actinopterygii, Gobiidae) in non-native species of Eğirdir Lake (Turkey). Acta Biologica Turcica 30: 1-6.

Harka Á, Szepesi Z, Sallai Z. 2015a. Spreading of the tubenose goby (Proterorhinus semilunaris), the monkey goby (Neogobius fluviatilis) and the Caucasian dwarf goby (Knipowitschia caucasica) in the water system of the River Tisza. Pisces Hungarici 9: 19-30 (in Hungarian)

Harka Á, Szepesi Z, Bajić A, Sipos S. 2015b. First record of the invasive Caucasian dwarf goby - Knipowitschia caucasica (Berg, 1916) - in Serbia. Pisces Hungarici 9: 89-92.

Hayden TA, Miner JG. 2009. Rapid dispersal and establishment of a benthic Ponto-Caspian goby in Lake Erie: diel vertical migration of early juvenile round goby. Biol Invasions 11: $1767-1776$.

Juza T, Zemanová J, Tušer M, Sajdlová Z, Baran R, Vašek M, ... \& Kubečka J. 2015. Pelagic occurrence and diet of invasive round goby Neogobius melanostomus (Actinopterygii, Gobiidae) juveniles in deep well-mixed European reservoirs. Hydrobiologia 768: 197-209.

Kevrekidis T, Kokkinakis AK, Koukouras A. 1990. Some aspects of the biology and ecology of Knipowitschia caucasica (Teleostei: Gobiidae) in the Evros Delta (North Aegean Sea). Helgoländer Meeresunters 44: 173-187.

Koblitskaya AF. 1961. New data on the biology of bubyr goby Pomatoschistus caucasiscus (Kaw.) from the foredelta of the Volga. Vopr Ikhtiol 2: 253-261 (in Russian).

Kottelat M, Freyhof J. 2007. Handbook of European freshwater fishes. Publications Kottelat, Cornol, Berlin, 660 p.

Liao H, Pierce CL, Larscheid JG. 2001. Empirical assessment of indices of prey importance in the diets of predacious fish. T Am Fish Soc 130: 583-591.

McCauley E. 1984. The estimation of the abundance and biomass of zooplankton in samples. In Downing JA, Rigler FH, eds. A Manual for the assessment of secondary productivity in fresh waters, Blackwell Scientific Publishers, Boston, MA, 228-265.

Menzie CA. 1981. Production ecology of Cricotopus sylvestris (Fabricius) (Diptera: Chironomidae) in a shallow estuarine cove. Limnol Oceanogr 26: 467-481.

Neer VW, Wildekamp RH, Kucuk F, Ünlüsayın M. 1999. First inland records of the euryhaline goby Knipowitschia caucasica from lakes in Anatolia, Turkey. J Fish Biol 54: 1334-1337.

Olson DS, Janssen J. 2017. Early feeding of round goby (Neogobius melanostomus) fry. J Great Lakes Res 43: 728-736.

Özkan N, Moubayed-Breil J, Çamur-Elipek B. 2010. Ecological analysis of chironomid larvae (Diptera, Chironomidae) in Ergene River basin (Turkish Thrace). Turk J Fish Aquat Sc 10: 93-99.

Özuluğ M, Tarkan AS, Gaygusuz Ö, Gürsoy Ç. 2007. Two new records for the fish fauna of Lake Sapanca Basin (Sakarya, Turkey). J Fish Sci 1: 152-159.

Pan'kov AV. 2007. First find of the Caucasian goby, Knipowitschia caucasica (Pisces, Gobiidae), in the freshwaters of Ukraine. Vestn Zool 41: 92 (in Ukrainian).

Shandikov VA, Kryvokhyzha DV, Slipko IV. 2009. A first record of the Caucasian dwarf goby, Knipowitschia caucasica (Teleostei, Perciformes, Gobiidae), in the Siverskiy Donets River drainage, Ukraine. Vestn Zool 43: 368.

Smirnov AI. 1986. Fauna of Ukraine. Fishes. Vol. 8, no. 5, Naukova Dumka, Kiev, 320 p. (in Russian).

Števove B, Kováč V. 2016. Ontogenetic variations in the diet of two invasive gobies, Neogobius melanostomus (Pallas, 1814) and Ponticola kessleri (Günther, 1861), from the middle Danube (Slovakia) with notice on their potential impact on benthic invertebrate communities. Sci Total Environ 557-558: $510-519$.

Troitskii SK, Tsunikova EP. 1978. Biology of Pomatoschistus caucasicus (Pisces, Gobiidae) in Kuban estuaries. Vestn Zool 5: 85-87 (in Russian).

USEPA. 2010. User's Guide and Technical Documentation KABAM Version 1.0. U.S. Environmental Protection Agency, Washington, DC, $123 \mathrm{p}$.

Vašek M, Všetičkovál, Roche K, Jurajda P. 2014. Diet of two invading gobiid species (Proterorhinus semilunaris and Neogobius melanostomus) during the breeding and hatching season: no field evidence of extensive predation on fish eggs and fry. Limnologica 46: 31-36.

Všetičková L, Janáč M, Vašek M, Roche KF, Jurajda P. 2014. Non-native western tubenose gobies Proterorhinus semilunaris show distinct site, sex and age-related differences in diet. Knowl Manag Aquat Ecol 414: 10. 
A. Didenko et al.: Knowl. Manag. Aquat. Ecosyst. 2020, 421, 26

Watkins J, Rudstam L, Holeck K. 2011. Length-weight regressions for zooplankton biomass calculations - A review and a suggestion for standard equations. Cornell Biological Field Station Publications and Reports, Bridgeport, NY, 17 p.
Zinchenko TD. 2011. Ecological and faunal review of chironomids (Diptera, Chironomidae) of small rivers in Middle and Low Volga basin (Atlas). Togliatti, Kassandra. 258 p. (in Russian with English abstract)

Cite this article as: Didenko A, Buzevych I, Volikov Y, Kruzhylina S, Gurbyk A. 2020. Population dynamics and feeding ecology of the invasive Caucasian dwarf goby, Knipowitschia caucasica, in a freshwater habitat in Ukraine. Knowl. Manag. Aquat. Ecosyst., $421,26$. 


\section{Appendix}

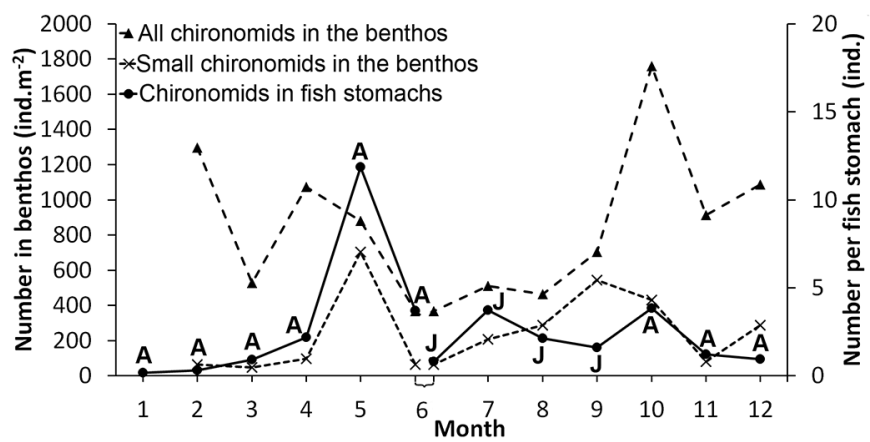

Fig. A1. Seasonal dynamics of the abundance of benthic chironomid larvae (all sizes and small sizes $\leq 5 \mathrm{~mm}$ ) at the sampling site and the average number of chironomid larvae per fish in gut contents of the Caucasian dwarf goby (A - adult-sized fish, $\mathrm{J}-$ juveniles).

Table AI. Diet composition of the Caucasian dwarf goby at the sampling site (all length groups and seasons pooled), where $\% \mathrm{~N}=$ relative abundance of prey items, $\% \mathrm{~W}=$ percentage of biomass, $\% \mathrm{~F}=$ frequency of occurrence.

\begin{tabular}{llll}
\hline & $\% \mathrm{~N}$ & $\% \mathrm{~W}$ & $\% \mathrm{~F}$ \\
\hline Oligochaeta & 0.06 & 1.11 & 0.63 \\
Dreissena polymorpha & 0.02 & 0.93 & 0.32 \\
Anodonta glochidia & 0.13 & 0.14 & 0.63 \\
Cladocera & & & \\
Bosmina longirostris & 4.48 & 0.81 & 7.94 \\
Bosmina coregoni & 0.32 & 0.1 & 0.32 \\
Chydorus sphaericus & 2.34 & 0.81 & 18.73 \\
Sida crystallina & 0.04 & 0.06 & 0.32 \\
Ceriodaphnia sp. & 0.82 & 0.36 & 4.44 \\
Alona affinis & 0.77 & 0.72 & 7.62 \\
Alona sp. & 3.23 & 1.76 & 16.51 \\
Pseudochydorus globosus & 0.76 & 0.63 & 5.71 \\
Pleuroxus aduncus & 1.23 & 0.87 & 12.06 \\
Pleuroxus sp. & 0.06 & 0.04 & 0.95 \\
Disparalona rostrata & 6.97 & 4.15 & 17.78 \\
Graptoleberis testudinaria & 0.24 & 0.17 & 1.90 \\
Camptocercus sp. & 0.19 & 0.22 & 2.54 \\
Alonella sp. & 0.04 & 0.01 & 0.01 \\
Acroperus harpae & 7.27 & 2.72 & 21.59 \\
Scapholeberis mucronata & 0.06 & 0.01 & 0.63 \\
Eurycercus lamellatus & 0.59 & 1.02 & 2.86 \\
Diaphanosoma sp. & 8.33 & 2.02 & 4.76 \\
Simocephalus sp. & 0.17 & 0.23 & 1.59 \\
Anchistropus emarginatus & 0.74 & 0.45 & 1.90 \\
Leptodora kindtii & 0.04 & 0.06 & 0.63 \\
Copepoda & & & \\
Cyclopoida & 41.74 & 34.97 & 75.24 \\
Harpacticoida & 0.46 & 0.07 & 5.40 \\
Ostracoda & 0.04 & 0.05 & 0.63 \\
Amphipoda & 0.02 & 0.28 & 0.32 \\
Acari & 0.02 & 0.09 & 0.32
\end{tabular}

Table AI. (continued).

\begin{tabular}{lll}
\hline$\% \mathrm{~N}$ & $\% \mathrm{~W}$ & $\% \mathrm{~F}$ \\
\hline
\end{tabular}

Insects

Chironomidae larvae

Chironomus sp.

Cladotanytarsus mancus

Corynoneura celeripes

Cricotopus algarum

Cricotopus sylvestris gr.

Cryptocladopelma viridula

Endochironomus albipennis

Glyptotendipes sp.

Dicrotendipes nervosus

Dicrotendipes tritomus

Microtendipes pedellus

Parachironomus vitiosus

Paratanytarsus lauterborni

Polypedilum convictum

Polypedilum nubeculosum

Polypedilum sordens

Polypedilum sp.

Psectrocladius psilopterus

Stictochironomus histrio

Tanytarsus gregarius

Trissocladius potamophilus

Trissocladius sp.

Chironomidae pupae

Ceratopogonidae

0.89

0.06

0.06

0.13

7.53

0.06

0.76

0.52

0.89

0.06

0.06

2.02

2.47

1.27

0.13

0.13

0.25

0.51

0.13

0.06

0.06

0.19

0.32

Ephemeroptera

Caenis sp.

0.02

$4.1 \quad \mathrm{n} / \mathrm{a}$

Baetis sp.

0.06

0.07

0.02

0.27

10.07

0.14

2.86

3.36

1.42

0.14

0.14

3.23

2.98

7.57

0.2

0.74

0.59

0.81

0.85

0.07

0.4

2.93

0.74

0.12

$\mathrm{n} / \mathrm{a}$

$\mathrm{n} / \mathrm{a}$

$\mathrm{n} / \mathrm{a}$

$\mathrm{n} / \mathrm{a}$

$\mathrm{n} / \mathrm{a}$

$\mathrm{n} / \mathrm{a}$

$\mathrm{n} / \mathrm{a}$

$\mathrm{n} / \mathrm{a}$

$\mathrm{n} / \mathrm{a}$

$\mathrm{n} / \mathrm{a}$

$\mathrm{n} / \mathrm{a}$

$\mathrm{n} / \mathrm{a}$

$\mathrm{n} / \mathrm{a}$

$\mathrm{n} / \mathrm{a}$

$\mathrm{n} / \mathrm{a}$

$\mathrm{n} / \mathrm{a}$

$\mathrm{n} / \mathrm{a}$

$\mathrm{n} / \mathrm{a}$

$\mathrm{n} / \mathrm{a}$

$\mathrm{n} / \mathrm{a}$

n/a

$\mathrm{n} / \mathrm{a}$
5.08

Trichoptera

Orthotrichia sp.

0.06

0.14

0.32

Other Trichoptera

0.04

0.17

0.95

0.95

Micronecta scholtzi

0.07

0.63

0.06

0.87

0.95

0.02

0.07 
A. Didenko et al.: Knowl. Manag. Aquat. Ecosyst. 2020, 421, 26

Table AII. Diet composition of three length groups (TL) of the Caucasian dwarf goby in the Stugna River: \%F = frequency of occurrence; $\% \mathrm{IRI}=$ percent index of relative importance.

\begin{tabular}{|c|c|c|c|c|c|c|}
\hline \multirow[t]{3}{*}{ Prey item } & \multicolumn{6}{|c|}{ Length group } \\
\hline & \multicolumn{2}{|c|}{$<20 \mathrm{~mm}(n=23)$} & \multicolumn{2}{|c|}{$20-29 \mathrm{~mm}(n=173)$} & \multicolumn{2}{|c|}{$>29 \mathrm{~mm}(n=119)$} \\
\hline & $\% \mathrm{~F}$ & $\%$ IRI & $\% \mathrm{~F}$ & $\%$ IRI & $\% \mathrm{~F}$ & $\%$ IRI \\
\hline Oligochaeta & & & 0.58 & $<0.01$ & 0.84 & 0.02 \\
\hline Dreissena polymorpha & & & & & 0.84 & 0.01 \\
\hline Anodonta glochidia & & & 0.58 & $<0.01$ & 0.84 & $<0.01$ \\
\hline Bosmina longirostris & 47.83 & 10.56 & 6.94 & 0.49 & 1.68 & 0.02 \\
\hline Bosmina coregoni & & & 0.58 & $<0.01$ & & \\
\hline Chydorus sphaericus & 34.78 & 3.68 & 18.50 & 0.40 & 15.97 & 0.56 \\
\hline Sida crystallina & 4.35 & 0.18 & & & & \\
\hline Ceriodaphnia sp. & 17.39 & 1.60 & 5.20 & 0.08 & 0.84 & $<0.01$ \\
\hline Alona affinis & 4.35 & 0.07 & 6.36 & 0.09 & 10.08 & 0.13 \\
\hline Alona sp. & 4.35 & 0.27 & 13.29 & 0.57 & 23.53 & 1.19 \\
\hline Pseudochydorus globosus & & & 5.20 & 0.07 & 7.56 & 0.11 \\
\hline Pleuroxus aduncus & 17.39 & 1.65 & 10.40 & 0.13 & 13.45 & 0.29 \\
\hline Pleuroxus sp. & 4.35 & 0.06 & & & 1.68 & $<0.01$ \\
\hline Disparalona rostrata & 17.39 & 1.84 & 19.65 & 1.70 & 16.81 & 2.20 \\
\hline Graptoleberis testudinaria & 4.35 & 0.06 & 1.73 & 0.01 & 1.68 & 0.01 \\
\hline Camptocercus sp. & & & 3.47 & 0.02 & 1.68 & $<0.01$ \\
\hline Alonella sp. & 8.70 & 0.16 & & & & \\
\hline Acroperus harpae & & & 23.70 & 2.36 & 22.69 & 2.22 \\
\hline Scapholeberis mucronata & & & 1.16 & $<0.01$ & & \\
\hline Eurycercus lamellatus & & & 2.31 & 0.02 & 4.20 & 0.09 \\
\hline Diaphanosoma sp. & 8.70 & 0.17 & 7.51 & 1.34 & & \\
\hline Simocephalus sp. & & & 2.89 & 0.03 & & \\
\hline Anchistropus emarginatus & & & 0.58 & $<0.01$ & 4.20 & 0.08 \\
\hline Leptodora kindtii & & & 1.16 & $<0.01$ & & \\
\hline Cyclopoida & 39.13 & 15.98 & 76.88 & 71.88 & 79.83 & 40.81 \\
\hline Harpacticoida & 26.09 & 1.34 & 4.62 & 0.02 & 2.52 & $<0.01$ \\
\hline Ostracoda & & & 0.58 & $<0.01$ & 0.84 & $<0.01$ \\
\hline Amphipoda & & & & & 0.84 & $<0.01$ \\
\hline Acari & & & 0.58 & $<0.01$ & & \\
\hline Chironomidae larvae & 82.61 & 62.38 & 58.38 & 20.68 & 76.47 & 52.19 \\
\hline Chironomidae pupae & & & 4.62 & 0.06 & 6.72 & 0.06 \\
\hline Caenis sp. & & & 1.73 & 0.01 & & \\
\hline Baetis sp. & & & 1.16 & $<0.01$ & 0.84 & $<0.01$ \\
\hline Orthotrichia sp. & & & 1.16 & $<0.01$ & & \\
\hline Other Trichoptera & & & 1.16 & 0.02 & 0.84 & $<0.01$ \\
\hline Micronecta scholtzi & & & 0.58 & $<0.01$ & & \\
\hline Ceratopogonidae & & & & & 0.84 & $<0.01$ \\
\hline
\end{tabular}

